\title{
Die etos van die Nederduitsch Hervormde Kerk
}

J H Koekemoer

Universiteit van Pretoria

\begin{abstract}
The ethos of the Nederduitsch Hervormde Kerk

In this article two aspects of the Reformed ethos of the Nederduitsch Hervormde Kerk van Afrika come to the fore. First, attention focuses on truth as encounter. Truth is not something neutral but something that involves the self, and is as such apprehended not by a solitary intellect, but by the whole person in fellowship with God. In the second place attention is given to the importance of the confessional tradition and its interpretation in Reformed theology.
\end{abstract}

\section{INLEIDING}

Die verwoording van wat met Hervormde etos bedoel word, is nie so maklik nie. Ons het hier nie met 'n voor die hand liggende saak te doen nie. Daar word tevergeefse pogings aangewend om dit in boeke terug te vind. Veral in Hervormde teologie is daar 'n terughoudendheid om hieroor te praat. 'n Teologie wat hoofsaaklik gekenmerk word deur ontdekkende nederigheid, praat moeilik oor homself. Hou verder in gedagte dat dit hier eerder om 'n lewenswyse as om logiese konstruksies gaan; en die huiwering om dit onder woorde te bring word meer verstaanbaar.

In my poging gaan ek veral op twee sake konsentreer wat in die huidige gesprek van wesenlike belang is. Uiteraard kan daar baie ander aspekte ook in die gesigsveld kom, maar hopelik sal dit vir $\mathrm{u}$ voor die handliggend wees waarom ek veral na die teologiese beskouing oor die waarheid en die invloed daarvan op die beskouing oor en hantering van die belydenisskrifte wil wys. In 'n huidige gesprek oor kerklike etos tree die verskil tussen Hervormde teologie en gereformeerde ortodoksie en liberale teologie hierin sterk op die voorgrond. En laat ek dit maar benadruk, beide gereformeerde ortodoksie en liberale teologie, wat ons wesenlik bedreig, is 'n siekte ten dode.

* Voordrag gelewer voor die Predikantevergadering van die Nederduitsch Hervormde kerk van Afrika op 13 September 1995. 
Hervormde teologie, wat die etos bepaal en tegelyk weer deur die etos bepaal word, het uit die aard van sy agtergrond homself steeds wyer gekenskets. Iets van 'n ekumeniese gerigtheid het na vore getree in die gebruikmaking van die term Bybels-reformatories, dit sluit immers Luthers in. Dit is iets anders as gereformeerde teologie - daarom is die etos wat daaruit na vore tree en wat dit tegelyk ten grondslag lê, ook anders. Dit is net so min liberale teologie.

Die Hervormde tradisie (lewenswyse, bestaanswyse) in ons land het daaruit sy gestalte gekry dat die kerk in sy teologie vir 'n sogenaamde derde opsie gekies het (Loader 1987:48). Pont (1994:106) beskryf die keuse van 'n ander opsie as 'n keuse, tussen 'die juridies konfessionele' rigting aan die een kant en die 'subjektiewe teologie' van die metodisme aan die ander kant. Loader beskryf die derde opsie as Eties. Eties word dan so verstaan dat dit nie 'sedelik' beteken nie, maar dat dit 'n aanduiding is dat die wese van die waarheid vir Hervormde teologie in die sentrum van belangstelling staan.

Hierdie opsie word aan die eenkant begrens deur die 'gereformeerde ortodoksie' waarmee Hervormde teologie hom nooit kon vereenselwig nie, en aan die anderkant deur die liberale teologie wat ewe-eens onaanvaarbaar is. Sonder om hierdie teologiese keuse hier breedvoerig te beredeneer, is dit tog nodig om te stel dat hierdie derde opsie nie 'n middeweg tussen die ander twee opsies is nie. Dit is 'n totaal ander opsie, 'n opsie waarin die waarheid nie in menslike konstruksies vasgevang kan word nie. Dit beteken egter nie dat die waarheid nie kenbaar is nie. Die mens kan wel daarmee in aanraking kom. Dit is wel waar dat die waarheid nie in 'n leer vasgevang kan word nie, omdat dit alle konsepte en proposisies wat gebruik word om dit uit te dra, transendeer; tog kan die mens met die waarheid in aanraking kom; word hy daarmee gekonfronteer. Laat ek dit anders sê: alhoewel die mens God nie kan deurgrond nie, kan hy God ontmoet. Die Woord het immers mens geword. Kom ek sê dit nog anders: die Woord het die gestalte van ons geskiedenis aangeneem, Hy het self geskiedenis geword. Die ewigheid het Homself in jaartalle uitgedruk. Dit beteken egter nie dat God nou so deel van die geskiedenis is dat hy voor die handliggend is nie (Berkhof $1973: 32 ; 1982: 59$ ). Daarom is hier van 'n verborgenheid sprake. Hier is 'n paradoks merkbaar. Juis daarom het Hervormde teologie altyd vasgehou aan die begrip van die waarheid as ontmoeting. God tree ons egter nie opsigtelik tegemoet nie. Die Woord verberg Homself in die vlees. Hy neem die gestalte van 'n dienskneg aan. Hoe die mens ook al daarna verlang dat die Openbaring in die menslike wêreld sigbaar, konstrueerbaar en verwoordbaar moet wees, is die openbaring op ' $n$ verborge wyse teenwoordig. Alhoewel hierdie goddelike teenwoordigheid vir misverstand en selfs verwerping vatbaar is, word die mens beskerm deur hierdie kreatuurlike bemiddeling 
omdat die mens God se naakte teenwoordigheid nie kan verduur nie (Barth:1960:19). Die Woord het mens geword. Juis in sy menslikheid is Hy die Openbaarder. Dit is waar, sy eie mense sien sy heerlikheid. God laat hulle dit sien. As hulle dit nie kon sien nie, sou daar van Openbaring geen sprake wees nie. Dit is die paradoks wat ter sprake kom (Koekemoer 1991:19).

Dit is die onmoontlike moontlikheid wat God skep. God se openbaring is teenwoordig in verborgenheid. Tog is hierdie verborgenheid van God se openbaring onder ons teenwoordig (Bultman 1971:63).

Hierdie teologiese idioom is in 1948 deur Haitjema (1948:7) as 'n keuse ten gunste van 'n eksistensieel-teologiese en dialekties paradoksale benadering beskryf. G C van Niftrik (1953:19) noem dit 'n teologiese denkpatroon wat eksistensieel wil wees. Dat ons eie verstaan in die rigting beweeg, lyk vir my logies. Hoekom anders het die dialektiese teologie van onder andere Karl Barth, Emil Brunner en Rudolf Bultmann so 'n invloed op ons teologiese verstaan uitgeoefen?

Die Waarheid is immers 'n Waarheid wat my aangaan, ek word daardeur gekonfronteer. Daarom kan die mens nooit as ' $n$ toeskouer oor die Waarheid praat nie, maar alleen as iemand wat eksistensieel deur God gegryp is. Menslike spreke tree eers na vore uit sy aangesproke wees.

In 'n proefskrif oor P J Müller oordeel C J Mans (1967:494) dat ons binne die Nederduitsch Hervormde Kerk van 'n getemperde konfessionele benadering kan praat. Hy noem dit so omdat daar by hom die oortuiging leef dat in sy poging om die verhouding God-mens teologies te deurdink, die Hervormde teologie daarop bedag was enis om nie in 'n konfessionalisme te verval nie, maar aan die anderkant ook nie konfessieloos en vrysinnig te wil wees nie. Daar was nog altyd die erkenning dat die mens ook binne 'n geloofs- en konfessionele tradisie leef waarin telkens weer oor God gepraat is en steeds gepraat moet word. Hierdie menslike gesprek verstar egter nooit op so 'n wyse dat dit in God verander nie en so die werk van die Gees vernietig nie.

Teologie is nie ' $n$ esoteriese bedryf nie. Dit is denkarbeid ten dienste van die kerklike verkondiging waarin die belydenistradisie ernstig geneem word. Die vooronderstelling is egter dat hierdie belydenisformule nooit sal verstar nie. Want sodra dit gebeur, is geloof nie meer ' $n$ lewe coram Deo nie, maar is dit die intelektuele aanvaarding van verstarde dogmas wat die kerk deur die loop van die eeue vasgestel het.

Soos reeds gestel was dit nog altyd binne Hervormde teologie so dat denke en spreke oor God uit 'n ontmoeting na vore tree en dat dit tegelyk weer gerig is op 'n ontmoeting met God. Die ontdekkende nederigheid in ons eie teologiebeoefening tree juis na vore uit ' $n$ innerlike oortuiging dat geen leerstuk, dogma of sisteem die volle waarheid van God kan omvat nie. Tog dink en praat ons in leerstukke, dogmas en 
sisteme. Dit is dus nie sinloos nie; maar feilbare en tog eerbare menslike pogings om die onsêbare te sê. So word die kerklike leer nie onbelangrik nie, maar word dit geplaas binne die ontmoetingsgebeure met God, as die kerklike verwoording van die ontmoeting ten dienste van 'n nuwe ontmoeting (kyk ook Berkhof 1973:32; Ott 1974:79).

Geloofsbelydenisse moet daarom steeds gelees word teen die agtergrond van 'n bepaalde geloofstradisie wat die ontstaan daarvan beinvloed het. Dit is die huidige geslag wat eksistensieël moet bely. Ons doen dit egter nie in isolasie nie. Die vadere, wat saam met ons die een heilige algemene kerk is, het ook inspraak. Hulle inspraak tree in ons belydenistradisie na vore. Ons moet dit ernstig neem. Maar dit is nie goed genoeg om net te herhaal wat hulle inspraak na vore roep nie. Wie dit doen het nog nie self tot belydenis gekom nie. Hy het nog nie eers regtig 'n ernstige poging aangewend om na die stemme uit die verlede te luister nie. Belydenis is 'n eksistensiële saak coram Deo. Juis dit maak die saak so ernstig. En hierin het beide ons en die vadere die een gemeenskaplike bron. Daarom oordeel M J Goddefroy (1989:11) reg as hy sê dat die suiwere leer by Hervormers nooit of te nimmer die leer van hulle vadere, of die konsilies is nie, maar altyd en alleen wat die Heilige Skrif leer.

Nou moet in die huidige konteks een saak my nog van die hart af. Volgens inligting vind daar tans weer in die Nederduitsch Hervormde Kerk bepaalde groepvorming plaas wat, so vrees ek andermaal tot gevolg kan hê dat verdagmaking navore tree. Hierteen sou ek ernstig en dringend wil waarsku. Die Kerk kan dit nie bekostig nie. Dit bly vir my 'n raaisel hoe deur die loop van die geskiedenis mense steeds probeer om die kerk teen die Here te beskerm, maak nie saak of hulle in die kleed van konserwatisme of liberalisme geklee is nie.

Die brandende vraag van die belydenis is nie die prerogatief van groepe, geheim of openbaar nie. Dit is die vraag van die kerk. En dit tree daar na vore waar die kerk in sy aanvegtinge konkreet niks anders kan doen nie as om te bely nie. Juis in sy konkrete nood kom die kerk, en nie drukgroepe in die kerk nie, tot 'n eksistensiële belydenis. Dit het tydens die Reformasie gebeur. En ek beroep my graag op Karl Barth (1936:150) as hy hieroor sê dat dit indringender is as 'n blote besinning oor die belydenis en 'n gesprek oor die noodsaak van belydenisskrifte.

Die reformatoriese belydenis word nêrens anders toegeëien as juis daar waar die kerk konkreet bely nie. Indien dit ons erns is, behoort ons ons gemeenskaplike belydenistradisie met erns ons eie te maak en opnuut onder woorde te bring. Die nood van die tyd roep ons daartoe. 'n Vasgevang wees in 'n tradisionalisme is net so gevaarlik as die geheueverlies van die liberale teologie. Dit het die Roomse kerk tot sy skade en skande in die sestiende eeu uitgevind. 
Die geloof kan nooit maar net die intellektuele aanvaarding van objektiewe waarhede word nie. God openbaar immers nie waarhede aan ons nie, Hy openbaar homself. En deur ons gekonfronteer wees met die selfopenbaring kom ons op die skouers van vorige geslagte opnuut belydend voor Jesus Christus te staan. Jesus is die Here, so klink dit stamelend, maar tegelyk ook die Here is in Jesus teenwoordig. Hier vra jy nie alleen maar of die leer van die reformatore ook nog vir jou aanvaarbaar sou wees nie. Nee, hier leef slegs een begeerte by jou: om uit die leer van die reformatore die konsekwensies na alle kante te trek en so biddend die kerk van die huidige dag 'n sprekende en belydende kerk te laat word. Hier staan ons midde in die konkrete vraag: Hoe ons vanuit die reformatoriese belydenis, hier en nou konkreet coram Deo moet bely.

Die nederige antwoord op hierdie vraag, op grond van bogenoemde teologiese tradisie, kenskets 'n Hervormde etos. Laat dit ons erns wees.

\section{Literatuurverwysings}

Barth, K 1960. Die Kirchliche Dogmatik. Deel 2/1, 5e druk. Zollikon: Zürich Evangelischer Verlag.

Barth, K 1936. De belijdenis der reformatie en ons belijden in De Levende God, preken en voordrachten van Karl Barth, 199-168. Vertaling van P G van den Hooff, Amsterdam: W Ten Have, 119-168.

Berkhof, H 1973. Christelijk Geloof. Nijkerk: Callenbach.

Berkhof, H 1982. Inleiding tot die studie van die Dogmatiek. Kampen: J H Kok.

Goddefroy, M J 1989. Die kerkkwestie niet een leer - maar een levenskwestie.

Tweede druk. Den Haag: De Swart \& Zoon.

Haitjema, ThL 1948. Dogmatiek als apologie. Haarlem: De erven.

Koekemoer, J H Dogmatiek binne konfessionele verband. Professorale intreerede, Universiteit van Pretoria.

Loader, J A 1987. 'Tertium datur' - oor die etiese waarheidsbegrip. HTS 43, 46-57. Mans, C J 1967. Die lewe en werk van die dogmatikus P J Müller. DD-proefskrif, Universiteit van Pretoria.

Ott, H [1971] 1974. God. Richmond, Virginia: John Knox Press.

Pont, A D 1994. Historiese perspektiewe op kerklik-teologiese opleiding van die Nederduitsch Hervormde Kerk aan die Universiteit van Pretoria. HTS 50/1, 95110.

Van Niftrik, G C 1953. Kleine Dogmatiek. Nijkerk: Callenbach. 